\title{
Bimetallic Oxide Nanohybrid Synthesized from Diatom Frustules for the Removal of Selenium from Water
}

\author{
Megha Thakkar and Somenath Mitra \\ Department of Chemistry and Environmental Science, New Jersey Institute of Technology, Newark, NJ, USA \\ Correspondence should be addressed to Somenath Mitra; somenath.mitra@njit.edu
}

Received 15 July 2017; Revised 23 November 2017; Accepted 27 November 2017; Published 31 December 2017

Academic Editor: Amit Bhatnagar

Copyright (C) 2017 Megha Thakkar and Somenath Mitra. This is an open access article distributed under the Creative Commons Attribution License, which permits unrestricted use, distribution, and reproduction in any medium, provided the original work is properly cited.

\begin{abstract}
Frustules or the rigid amorphous silica cell wall of unicellular, photosynthetic microalgae with unique porous architecture has been used to synthesize a composite by immobilizing zirconium and iron oxides on its surface and in the pores. This was effective for removal of Se from water, which is an emerging contaminant that is a micronutrient at low concentrations but toxic at high concentrations. The adsorption isotherms followed both Langmuir and Freundlich models, and the composite was regenerable. The Langmuir maximum adsorption capacity for Se(IV) $\left(q_{m}\right)$ was $227 \mathrm{mg} / \mathrm{g}$, which is among the highest ever reported. The research findings highlight the synthesis of bimetallic composite as well as the potential of diatoms as hosts for nanomaterials for use in water treatment.
\end{abstract}

\section{Introduction}

Selenium is an important micronutrient for animals and humans but is toxic in excess [1]. Higher Se concentration can lower reproduction rates and increase birth defects $[2$, 3]. In water, selenium exists predominantly in inorganic forms selenite $\left(\mathrm{SeO}_{3}{ }^{2-}\right)$ where $\mathrm{Se}$ is present as the $\mathrm{Se}^{4+}$ and selenate $\left(\mathrm{SeO}_{4}{ }^{2-}\right)$ where selenium is present as the $\mathrm{Se}^{6+}[4]$. The toxicity of selenium depends on its oxidation state and $\mathrm{Se}(\mathrm{IV})$ is considerably more toxic than $\mathrm{Se}(\mathrm{VI})$ [5]. Drinking water is a primary source for selenium exposure and the US Environmental Protection Agency has set the maximum contaminant level in drinking water to be $0.05 \mathrm{mg} / \mathrm{L}$. Sources of Se include agricultural and mine drainage, residues from fossil fuel thermoelectric power plants, oil refineries, and metal ores [6].

A variety of treatment technologies have been explored for the remediation of both selenium oxoanions in water. These include bacterial reduction, membrane filtration, chemical reduction, reverse osmosis, and solar ponds [79]. These technologies have their limitations and alternative treatment techniques are being explored. Adsorption by metal oxides of iron and aluminum has shown promise in selenium removal [10]. Other materials like $\mathrm{Mg} / \mathrm{Fe}$ hydrotalcite type compounds, hematite, magnetite, iron-coated GAC, and magnetic $\mathrm{Fe} / \mathrm{Mn}$ oxide nanomaterials also have high affinity for selenium [11-15]. Adsorbents such as sulphuric acid-treated peanut shell, hydrocalumite, ettringite, $\mathrm{AlPO}_{4}$, biopolymeric materials, aluminum-based water treatment chemicals, hardened cement paste, cement minerals, aluminum oxides, iron oxyhydroxides, iron-coated sand, and zero valent iron [16-23] have also been tested for Se removal.

The search for more efficient water treatment media has led to the development of nanostructured adsorbents where metals, metal oxides, and ion-exchange medium are immobilized on supports that promote nanostructuring [24]. Along with the active sorbent(s), the support plays an important role. Properties like thermal, mechanical, and chemical aid in structuring of the active ingredient [24]. Consequently, composite or hybrid structures are promising materials for water treatment. The widely used host materials for nanocomposite include carbonaceous materials like granular activated carbon [25], silica [26-29], cellulose [30, $31]$, chitosan [32, 33], sand [34, 35], and polymers [36-38]. Some examples include the immobilization of metal oxides on carbon nanotubes for lead, arsenic, and fluoride removal 
[39-41], activated carbon immobilized on carbon nanotubes for chromium removal [25], and carbohydrate and iron oxide on multiwalled carbon nanotubes for zinc removal [42].

Diatoms are unicellular, photosynthetic microalgae that are widely distributed in fresh and seawater. Diatoms can self-replicate and can further be engineered to provide costeffective and programmable industrialized system [43]. There are over eleven thousand known species whose size ranges from $2 \mu \mathrm{m}$ to $2 \mathrm{~mm}$ and they also have diverse morphology [44]. Naturally occurring diatom frustules are a source of nanomaterials. Frustules, or the rigid amorphous silica cell wall of the diatoms, have unique porous architecture $[45,46]$ and high surface area [47]. Recently, they have found a variety of applications including water filtration membrane [48], gas sensor [49], electroluminescent display device [50], lithium battery electrode [50], dye sensitized solar cells [50], biochip [51], and drug delivery [52]. It is possible that the diatoms can serve as hosts for immobilizing active sorbent particles on their surface. The surface of the diatom can have different functionalities such as $-\mathrm{COOH},-\mathrm{NH}_{2},-\mathrm{OH}$, and $-\mathrm{SiOH}$, and different compounds can be immobilized on their surface by interactions with these functional groups $[53,54]$. They have been successfully used as templates for the synthesis of advanced nanostructured biohybrids. Diatom can be used in water filtration and purification due to different interesting properties likes filtration of microorganisms, homogenous permeability, and fixed pore size, USEPA approved [43]. Not much research is done on exploring diatom for water purification applications.

The objective of this research is to develop nanosorbents by immobilizing metal oxides on diatom surface and in pores of diatom frustules. It is well known that mixed metal oxides usually exhibit better sorption abilities than individual oxides in terms of higher capacities, $\mathrm{pH}$ tolerance, and faster kinetics $[55,56]$. Hydrous zirconium oxide is known to retain various oxo metal anions, especially those that can form weak conjugate acids [57]. It is also known to be chemically stable and nontoxic and does not dissolve in water at a wide range of $\mathrm{pH}$ [58]. At the same time, the iron oxides/hydroxides have been gaining popularity in water treatment and are known to adsorb Se [56]. Therefore, the specific objective is to develop a bimetallic oxide composite by immobilizing iron and zirconium oxides on diatom frustules for effective removal of Se from water.

\section{Materials and Methods}

2.1. Synthesis of Bimetallic Diatom Composite. Diatom Phaeodactylum tricornutum was cultured and maintained in artificial sea water Aquil [59] using a diurnal chamber with 12hour day/night cycles at $19^{\circ} \mathrm{C} \pm 1^{\circ} \mathrm{C} .6 \mathrm{~L}$ of diatom culture was flocculated with $6 \mathrm{~g}$ of $\mathrm{ZrOCl}_{2} \cdot 8 \mathrm{H}_{2} \mathrm{O}$ and $60 \mathrm{~g}$ of $\mathrm{FeCL}_{3} 6 \mathrm{H}_{2} \mathrm{O}$ purchased from Sigma Aldrich at $\mathrm{pH}$ 9. One molar $\mathrm{NaOH}$ was used to adjust the $\mathrm{pH}$ to 9 .

After flocculation, the culture was conditioned overnight with shaking ( $150 \mathrm{rpm}, 2880 \mathrm{VWR}$ orbital shaker). The resulting bimetallic diatom mixture was separated by gravitational settling and membrane filtration ( $<5$ psi, $0.2 \mu \mathrm{m}$ PTFE filter) and was washed with $500 \mathrm{~mL}$ Milli-Q water. The resulting slurry was transferred to $50 \mathrm{~mL}$ centrifuge tube and thermally treated at $70^{\circ} \mathrm{C}$ in an oven for $6 \mathrm{~h}$. Then, it was treated with $10 \mathrm{~mL}$ of concentrated $\mathrm{H}_{2} \mathrm{SO}_{4}$ and heated for $2 \mathrm{hrs}$ at $200^{\circ} \mathrm{C}$, vacuum-filtered using $0.2 \mu \mathrm{m}$ filter, washed with Milli-Q water to neutral $\mathrm{pH}$, and then dried at $200^{\circ} \mathrm{C}$ in a vacuum oven. The bimetallic oxide-diatom composite (BMDC) was characterized using transmission electron (HRTEM), scanning electron microscope equipped with energy dispersive $\mathrm{X}$ ray spectrometer (SEM, LEO $1530 \mathrm{VP}$ ), thermogravimetric analyzer (TGA using Pyris 1 from PerkinElmer Inc.), BET surface area analyzer (Quantachrome Autosorb-1), and FTIR (IR Affinity-1, Shimadzu).

2.2. Adsorption Studies. The kinetics of adsorption were performed as follows. 50 millilitres of $5 \mathrm{mg} / \mathrm{L}$ of Se(IV) and (VI) solutions was contacted with $0.010 \mathrm{~g}$ and $0.025 \mathrm{~g}$ of adsorbent in polycarbonate bottles and the samples were collected at 5 , 15 , and 30 minutes followed by $1,3,6$, and 24 hours. $5 \mathrm{~mL}$ aliquot was withdrawn at different time intervals and filtered using $0.2 \mu \mathrm{m}$ membrane filter and residual Se in the media was quantified using Agilent 7500 ICP-MS. All standards were prepared from multielement solution 2A, $10 \mathrm{mg} / \mathrm{L}$ (Spex Certiprep), with addition of internal standard mix (Li6, $\mathrm{Ge}, \mathrm{Y}, \mathrm{In}, \mathrm{Tb}$, and $\mathrm{Bi}$ ). Multielement instrument calibration standard, 1 and $20 \mathrm{mg} / \mathrm{L}$ (Spex Certiprep), was used for the verification of calibration. The adsorption capacity $\left(q_{e}\right)$ and adsorption isotherms were obtained by varying the mass of adsorbent from 0.002 to $0.015 \mathrm{~g}$ (Se IV) and 0.002 to $0.050 \mathrm{~g}$ $\mathrm{Se}(\mathrm{VI})$ with $50 \mathrm{~mL}$ of $5 \mathrm{mg} / \mathrm{L} \mathrm{Se}$ containing water at $\mathrm{pH}$. The samples were collected for analysis after 0,6 , and 24 hours of adsorption.

Adsorption was studied at $\mathrm{pH}$ values $2,4,6$, and 8 using 50 millilitres of $1 \mathrm{mg} / \mathrm{L} \mathrm{Se}(\mathrm{IV})$ solution that was contacted with $0.010 \mathrm{~g}$ of adsorbent for $24 \mathrm{~h}$. Desorption of selenium from the spent bimetallic diatom composite was carried out using $1 \mathrm{M}$ $\mathrm{NaCl}$ and $0.1 \mathrm{M} \mathrm{NaOH}$ solution. After selenium adsorption, the composite was washed with $1 \mathrm{M} \mathrm{NaCl}$, followed by distilled water and $0.1 \mathrm{M} \mathrm{NaOH}$.

\section{Results and Discussion}

3.1. Characterization of Bimetallic Oxide-Diatom Composite. Diatom Phaeodactylum tricornutum was grown till the late exponential phase [60]. After adding $\mathrm{ZrOCl}_{2} 8 \mathrm{H}_{2} \mathrm{O}$, $\mathrm{FeCl}_{3} 8 \mathrm{H}_{2} \mathrm{O}$, and $\mathrm{NaOH}$ to the diatom, $\mathrm{Zr}$ and $\mathrm{Fe}$ oxides were precipitated on the diatom surface and chemically attached with diatom functional groups such as $-\mathrm{COOH},-\mathrm{NH}_{2},-\mathrm{OH}$, and $-\mathrm{SiOH}$. This was enhanced by heat treatment at $70^{\circ} \mathrm{C}$ for $6 \mathrm{~h}$. Furthermore, $\mathrm{H}_{2} \mathrm{SO}_{4}$ treatment decomposed all the organic matter leaving algal core with $\mathrm{Zr}$ and Fe oxides on its surface. Mesoporous zirconia can be obtained by contacting amorphous hydrous zirconia obtained by alkaline hydrolysis with sulphuric acid followed by calcinations [61].

The presence of $\mathrm{Zr}$ and Fe particles on diatom surface was studied using SEM. Figure 1(a) shows SEM of the original diatom, Figure 1(b) shows bimetallic composite, and Figures 1(c) and 1(d) show mapping of $\mathrm{Zr}$ and Fe from BMDC. Similarly, Figures 1(e) and 1(f) show TEM image of the diatom and BMDC. SEM and TEM images showed that the original 


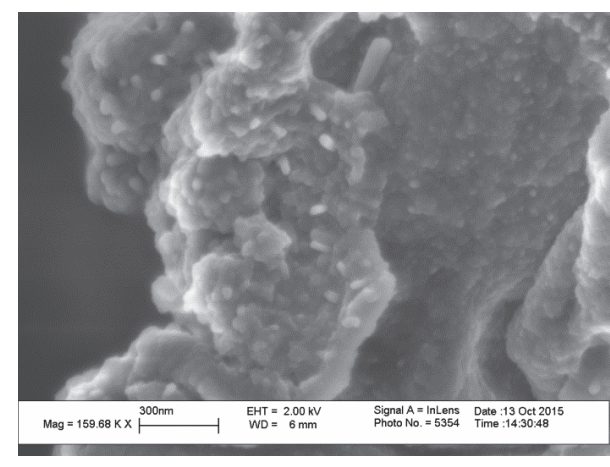

(a)

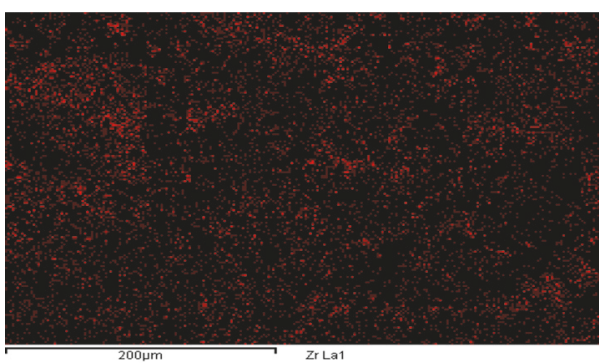

(c)

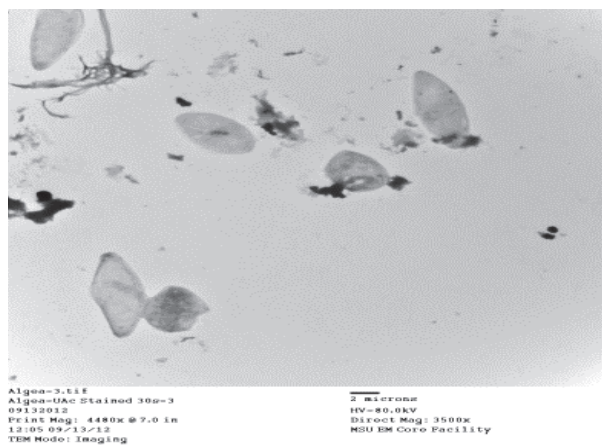

(e)

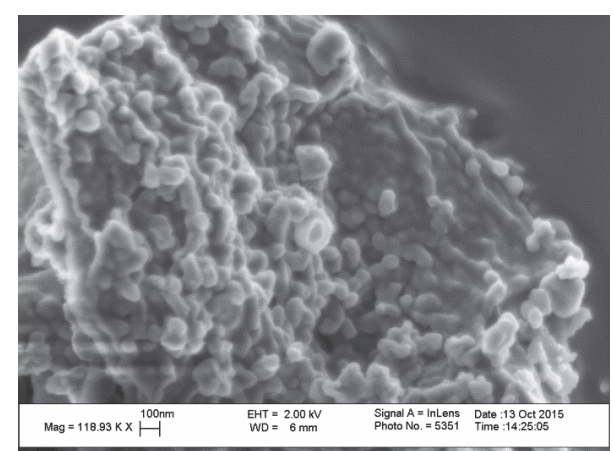

(b)

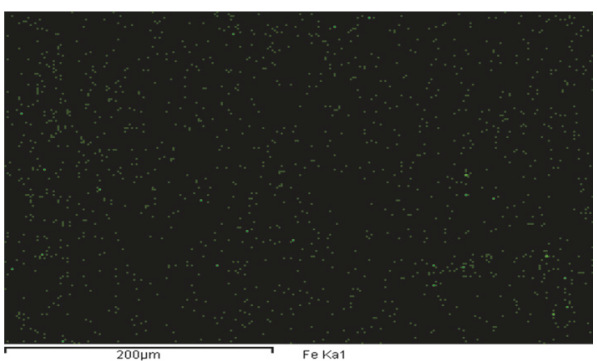

(d)

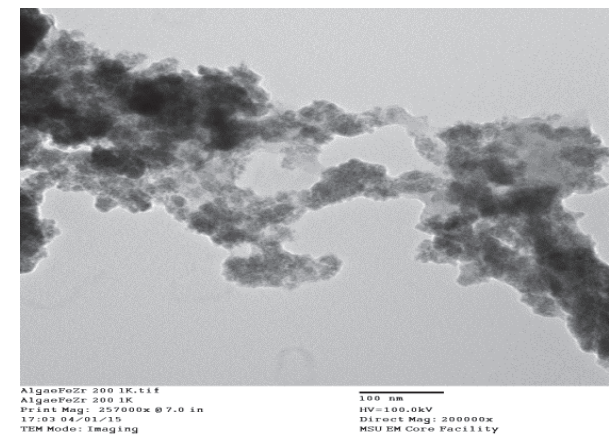

(f)

Figure 1: (a) SEM of diatom and (b) diatom bimetallic oxide composite; ((c), (d)) represent mapping for Zr and Fe immobilized on diatom surface. TEM of (e) diatom and (f) diatom bimetallic oxide composite.

diatom was reduced to porous nanobiosilica. EDX analysis using SEM confirmed the presence of $\mathrm{Zr}$ (89.87\%) and $\mathrm{Fe}$ $(8.75 \%)$ in BMDC.

The specific surface area of bimetallic diatom composite based on BET measurements was found to be $128 \mathrm{~m}^{2} / \mathrm{g}$ and pore diameter was $9.39 \AA$. The FTIR (Figure 2) was used to confirm the functional groups. The observed peak at $374-400 \mathrm{~cm}^{-1}$ was attributed to $\mathrm{Zr}-\mathrm{O}$ vibration, which confirmed the $\mathrm{ZrO}_{2}$ structure [62]. The observed peak at 551 $\mathrm{cm}^{-1}$ and around $700 \mathrm{~cm}^{-1}$ was attributed to Fe [63]. Both spectra showed peaks at 1108 and between $3300 \mathrm{~cm}^{-1}$ and $3500 \mathrm{~cm}^{-1}$. These were due to stretching of siloxane ( $\left.\mathrm{Si}-\mathrm{O}-\mathrm{Si}\right)$ and free silanol group ( $\mathrm{Si}-\mathrm{OH})[64]$.

TGA was used to test the thermal stability of the BMDC (Figure 3). The weight loss below $120^{\circ} \mathrm{C}$ was attributed to the removal of physisorbed water while the loss between 120 and $300^{\circ} \mathrm{C}$ was due to chemisorbed water [65]. In the $300-400^{\circ} \mathrm{C}$ range, the weight loss was from the oxidation and decomposition of mercaptopropyl or aminopropyl groups on diatom surface. The broad exothermic weight loss in the range of $400-600^{\circ} \mathrm{C}$ was due to the decomposition of strongly tethered organosilanes and dehydration of silanol groups, and the weight reduction between 400 and $800^{\circ} \mathrm{C}$ was due to the dehydroxylation of the silica surface $[66,67]$. TGA curve indicated that bimetallic diatom composite exhibited good thermal stability. It is worth noting that the observed weight loss $(25 \%)$ below $300^{\circ} \mathrm{C}$ was mainly ascribed to the evaporation of water. Only $15 \%$ of the mass remained as residue beyond $600^{\circ} \mathrm{C}$.

3.2. Selenium Removal Using BMDC. It was observed that no selenium was adsorbed on the pure diatom, but the BMDC was effective in removing selenium from water. Selenite and selenate uptake by BMDC was studied as a function of time and is presented in Figure 4. Selenium sorption increased as a function of contact time. $0.010 \mathrm{~g}$ of bimetallic composite 


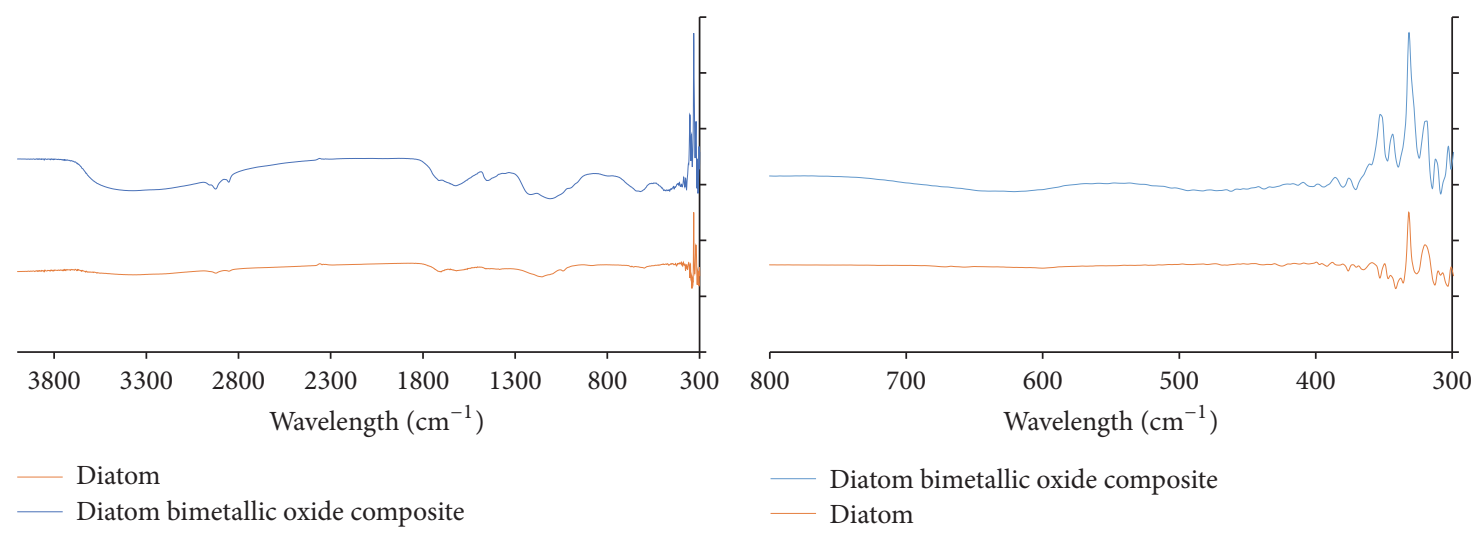

FIGURE 2: FTIR spectra of diatom and diatom bimetallic oxide composite.

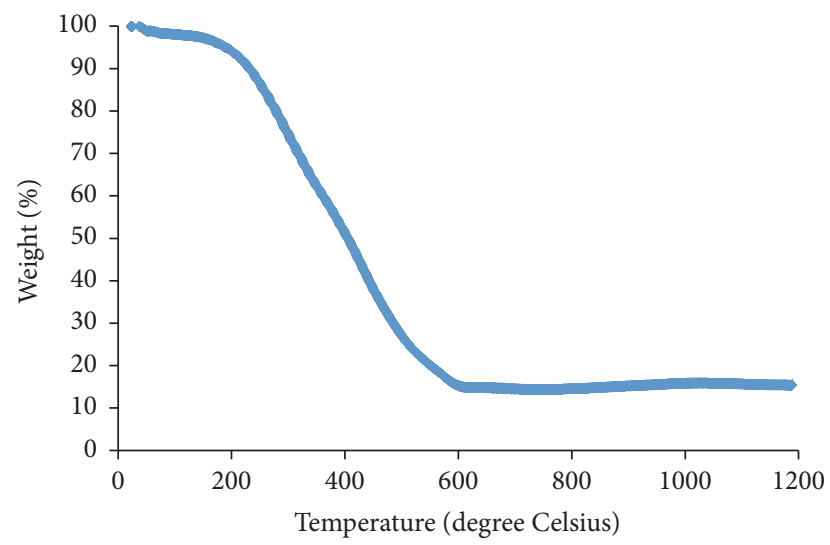

FIgURE 3: TGA of bimetallic oxide-diatom composite.

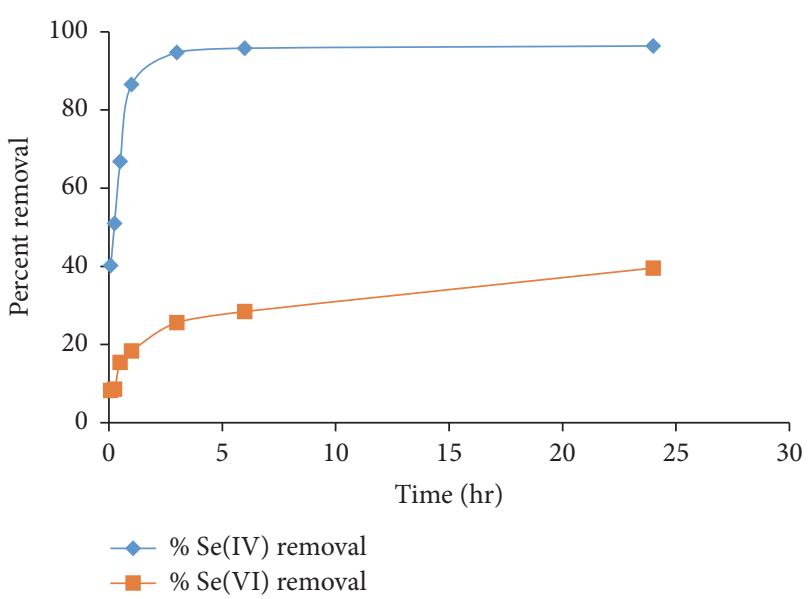

FIgure 4: Percent removal of $\mathrm{Se}(\mathrm{IV})$ and $\mathrm{Se}(\mathrm{VI})$ as a function of time.

showed Se(IV) uptake of 50 and $95 \%$ at 15 mins and $3 \mathrm{hrs,}$ respectively, whereas $0.025 \mathrm{~g}$ of bimetallic composite showed removal of only $40 \% \mathrm{Se}(\mathrm{VI})$ after $24 \mathrm{hrs}$ of contact. This shows that bimetallic diatom composite shows better Se(IV) removal efficiency compared with $\mathrm{Se}(\mathrm{VI})$.
TABLE 1: Experimental $q_{e}$, using different concentrations of adsorbent doses.

\begin{tabular}{|c|c|c|}
\hline $\begin{array}{l}\text { Initial adsorbent concentration } \\
(\mathrm{g})\end{array}$ & $\begin{array}{c}\text { Experimental } q_{e} \\
\mathrm{mg} / \mathrm{g}\end{array}$ & $\%$ removal \\
\hline \multicolumn{3}{|c|}{$\operatorname{Se}(\mathrm{IV})$} \\
\hline 0.001 & 56.24 & 56.24 \\
\hline 0.002 & 45.41 & 90.82 \\
\hline 0.005 & 19.12 & 95.64 \\
\hline 0.010 & 9.67 & 96.74 \\
\hline 0.015 & 6.45 & 96.80 \\
\hline \multicolumn{3}{|c|}{$\mathrm{Se}(\mathrm{VI})$} \\
\hline 0.002 & 10.61 & 21.23 \\
\hline 0.005 & 5.51 & 27.55 \\
\hline 0.010 & 3.26 & 32.60 \\
\hline 0.015 & 2.43 & 36.49 \\
\hline 0.050 & 0.89 & 44.90 \\
\hline
\end{tabular}

The amount of selenium adsorbed was calculated using the following equation:

$$
q_{e}=\frac{\left(C_{0}-C_{e}\right) V}{m}
$$

where $C_{0}$ and $C_{\mathrm{e}}(\mathrm{mg} / \mathrm{L})$ are the liquid-phase concentrations of selenium at initial and equilibrium concentrations, respectively, $V$ is the volume of solution in (L), and $m$ is the mass of the adsorbent used ( $\mathrm{g}$ ). Adsorbent dosage is an important parameter because this determines the capacity of an adsorbent. It was observed that, at equilibrium, the percentage removal increased with the increase in the adsorbent concentration while the adsorption capacity $q_{e}$ decreased. Table 1 presents $q_{e}$ at different adsorbent dosage. It was seen that the initial adsorbent dose affects the adsorption capacity; $q_{e}$ dropped from $56.24 \mathrm{mg} / \mathrm{g}$ for $0.001 \mathrm{~g}$ of adsorbent to $6.45 \mathrm{mg} / \mathrm{g}$ for $0.015 \mathrm{~g}$ for Se(IV) and $10.6 \mathrm{mg} / \mathrm{g}$ for $0.002 \mathrm{~g}$ of adsorbent to $0.89 \mathrm{mg} / \mathrm{g}$ for $0.05 \mathrm{~g}$ for $\mathrm{Se}(\mathrm{VI})$.

The kinetics of selenium uptake were studied using Lagergren [68] as well as Ho and McKay kinetic models [69]. The former models the rate of adsorption of pollutants based 
TABLE 2: First-order and second-order kinetics of selenium.

\begin{tabular}{lcccccc}
\hline & & & & \multicolumn{2}{c}{ Second-order } \\
& $q_{e}$ & First-order & $R^{2}$ & $q_{e}$ & $k$ \\
\hline Se(IV) & 1.92 & 0.0056 & 0.91 & 4.75 & 1.4 & 0.99 \\
$\operatorname{Se}(\mathrm{VI})$ & 0.564 & 0.0013 & 0.89 & 0.73 & 0.54 & 0.98 \\
\hline
\end{tabular}

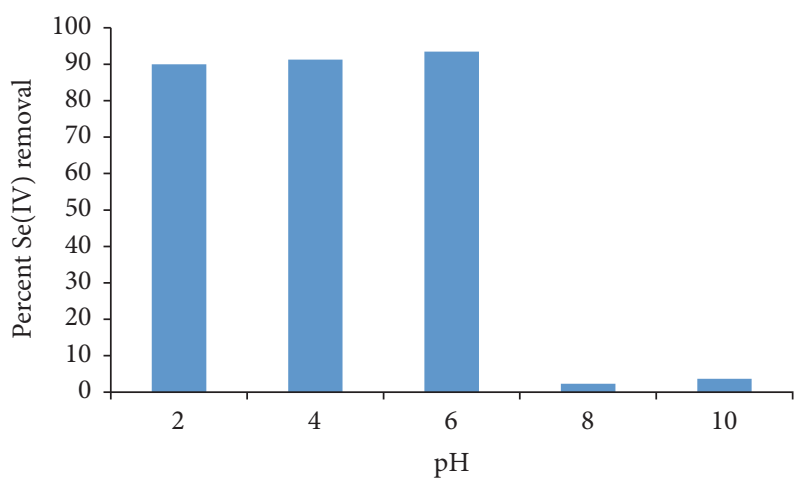

Figure 5: Effect of $\mathrm{pH}$ on $\mathrm{Se}(\mathrm{IV})$ removal.

on pseudo-first equation to describe the kinetics of liquidsolid phase adsorption [70].

$$
\log \left(q_{e}-q_{t}\right)=\log q_{e}-\frac{k_{1}}{2.303} t
$$

The rate constant $k_{1}$ was calculated from a linear plot of log $\left(q_{e}-q_{t}\right)$ verses $t$, where $q_{e}$ and $q_{t}$ are the sorption capacity $(\mathrm{mg} / \mathrm{g})$ of the adsorbent at equilibrium and at time $t\left(\mathrm{~h}^{-1}\right)$, and $k_{1}$ is the rate constant of pseudo-first order. The second-order equation from Ho and McKay is based on the assumption that adsorption may be of second order and the rate limiting step may be from chemical adsorption involving exchange of valence electrons [71]

$$
\frac{t}{q_{t}}=\frac{1}{k_{2} q_{e}^{2}}+\frac{t}{q_{e}} .
$$

The rate constant $k_{2}$ was calculated from a linear plot of $t / q_{t}$ versus $t$. Here $k_{2}$ is the pseudo-second-order sorption rate constant $(\mathrm{g} / \mathrm{h} / \mathrm{mg})$ and $t$ is time $\left(\mathrm{h}^{-1}\right)$. The applicability of first- and second-order models was tested for adsorption of selenium on BMDC. Table 2 presents the kinetic data. The best fit was selected based on the linear regression coefficient $R^{2}$. The models were fitted with the experimental data. Ho and McKay's second-order equation was found to be a better fit as compared with the first-order equation. The adsorption rates obtained from first- and second-order kinetic models are given in Table 2. In the first-order model, a larger adsorption rate constant usually represents quicker adsorption whereas in the second-order model, a lower value of $k$ represents faster adsorption. This is due to the availability of large number of binding sites.

The effect of $\mathrm{pH}$ was studied at 2, 4, 6, 8, and 10 (Figure 5). The variation in $\mathrm{pH}$ in the range of 2 to 6 did not show much effect on percent adsorption. With increase in $\mathrm{pH}$ from 6 to 10 , the adsorption capacity decreased. At low $\mathrm{pH}$ conditions, the $\mathrm{H}_{3} \mathrm{O}^{+}$ion concentration was optimum to make the surface of the BMDC positively charged and hence accessible for selenium ions. With an increase in $\mathrm{pH}$, especially in alkaline medium, the selenium uptake was reduced due to the competition with $\mathrm{OH}^{-}$, which also had high affinity for the zirconium and iron ion.

Langmuir [72] and Freundlich [73] isotherms provided an insight into the surface coverage via physisorption and/ or chemisorption. Langmuir isotherm best describes the chemisorption process. The adsorption involves the attachment of monolayer of molecules on the surface. The linear form of Langmuir adsorption isotherm, which involves a plot of $1 / q_{e}$ versus $1 / C_{e}$, is represented as

$$
\frac{1}{q_{e}}=\frac{1}{q_{m}}+\frac{1}{b q_{m} C_{e}} .
$$

Here, $q_{m}(\mathrm{mg} / \mathrm{g})$ is the maximum sorption capacity of the sorbent, $C_{e}(\mathrm{mg} / \mathrm{L})$ is the equilibrium selenium ion concentration, and Langmuir constant $b(\mathrm{~L} / \mathrm{mg})$ is indirectly related to the enthalpy of adsorption. The essential features of Langmuir adsorption parameters can be used to predict the affinity between the sorbent and the sorbate using the dimensionless separation factor which is expressed as follows:

$$
R_{L}=\frac{1}{1+b C_{0}},
$$

where $b$ is Langmuir constant and $C_{0}$ is initial concentration. $R_{L}$ indicates the nature of adsorption $\left(R_{L}\right.$ between 0 and 1 is considered favourable, $R_{L}<1$ is unfavourable, and $R_{L}=0$ is reversible) $[74,75]$.

The correlation coefficient $R^{2}$ for the Langmuir model was 0.956 , which demonstrated a high degree of correlation. The Langmuir parameters are presented in Table 3. The maximum adsorption capacity for Se(IV) on the composite was $277 \mathrm{mg} / \mathrm{g}$ and $\mathrm{Se}(\mathrm{VI})$ was $0.48 \mathrm{mg} / \mathrm{g}$ at $\mathrm{pH}$ 6. The Langmuir constant $b$, the ratio of adsorption rate constant to desorption rate constant, is an indication of affinity of the sorbent material towards selenium. Since $R_{L}$ was less than 1 , the adsorption was considered favourable. Hence Langmuir model effectively explained the selenium uptake by the bimetallic diatom composite.

Freundlich adsorption was also tested. In its linearized form, the Freundlich isotherm involves a plot of $\log q_{e}$ and $\log C_{e}$ :

$$
\log q_{e}=\log k_{f}+n \log C_{e} .
$$

The values for $\log k_{f}$ and $n$ were obtained as the intercept and slope, respectively (Table 3). A measure of adsorption capacity and adsorption intensity was provided by the Freundlich constants $k_{f}\left(\mathrm{mg} \mathrm{g}^{-1}\right)$ and $1 / n$, respectively. Here, $n$ 
TABLE 3: Model parameters of Langmuir and Freundlich isotherms for adsorption of selenium.

\begin{tabular}{lccccc}
\hline & & Langmuir model & \multicolumn{3}{c}{ Freundlich model } \\
& $q_{m}(\mathrm{mg} / \mathrm{g})$ & $b$ & $R^{2}$ & $n$ & $k_{f}$ \\
\hline $\mathrm{Se}(\mathrm{IV})$ & 277 & 0.205 & 0.95 & 1.21 & 0.0103 \\
$\mathrm{Se}(\mathrm{VI})$ & 0.48 & 0.252 & 0.95 & 6.07 & 0.95 \\
\hline
\end{tabular}

$q_{m}$ : the maximum sorption capacity of the sorbent; $b$ : Langmuir constant; $k_{f}$ : Freundlich constant; $R^{2}$ : correlation coefficient.

was an indicator of the degree of nonlinearity between water concentration and sorption $(n=1$ denotes linear adsorption, $n<1$ a chemisorption, and $n>1$ physisorption [76]). The bond energy increases proportionally with surface density for $n<1$ and vice versa for $n>1$. Values of $n$ being 0.47 and 0.45 implied that the adsorption was a chemical process and that the bond energy increased with surface coverage [73]. The correlation coefficient, $R^{2}$, was 0.95 .

Based on the second-order kinetics, Langmuir model, and Freundlich model, the adsorption appeared to be via a chemical process. Adsorption of Se can occur due to both outer and inner sphere complexation on metal oxides [77]. Selenate is known to be more strongly adsorbed than selenite at a wide range of $\mathrm{pH}$. As per the recent review, mixed metal oxide, double layered materials, and adsorbents based on natural materials have shown good sorption capacities and relative fast kinetics. It is worth mentioning that the sorption capacity from our study is comparable to those reported before. For example, $q_{m}$ of $2.38 \mathrm{mg} / \mathrm{g}$ was reported for selenate removal using $\mathrm{Fe}_{3} \mathrm{O}_{4}$ [78], $26.3 \mathrm{mg} / \mathrm{g}$ using $\mathrm{FeOOH}$ [77, 79], $29.0 \mathrm{mg} / \mathrm{g}$ using Fe-Mn hydrous oxide [24], and $74.9 \mathrm{mg} / \mathrm{g} \mathrm{Se}(\mathrm{IV})$ using green alga Cladophora hutchinsia [80]. Recent study on selenium removal using $\mathrm{MgO}$ sheets showed adsorption capacity of Se(IV) $103.52 \mathrm{mg} / \mathrm{g}$ and $\mathrm{Se}(\mathrm{VI})$ $10.58 \mathrm{mg} / \mathrm{g}$ [22]. Se(IV) Langmuir adsorption capacity of MNP@hematite is $25.0 \mathrm{mg} / \mathrm{g}$, MNP core $15.3 \mathrm{mg} / \mathrm{g}$, magnetic nanoparticle-graphene oxide $23.8 \mathrm{mg} / \mathrm{g}$ [81], $\mathrm{Al}(\mathrm{III}) / \mathrm{SiO} 2$ $20.4 \mathrm{mg} / \mathrm{g}$ [82], a-Fe2O3 $17.9 \mathrm{mg} / \mathrm{g}$ [83], Fe/Si coprecipitates $17.4 \mathrm{mg} / \mathrm{g}$ [20], MIO/MWCNTs $13.1 \mathrm{mg} / \mathrm{g}$ [21], CuFe2O4 $14.1 \mathrm{mg} / \mathrm{g}$ [19], and iron manganese oxide $6.57 \mathrm{mg} / \mathrm{g}$ [15].

Desorption of $\mathrm{Se}(\mathrm{IV})$ and regeneration of BMDC were studied by monitoring the effluent washes from a Se(IV) sorbed BMDC. $0.050 \mathrm{~g}$ of adsorbent was contacted with $50 \mathrm{~mL}$ of $2 \mathrm{mg} / \mathrm{L}$ of Se(IV) solution. After 24 hours of exposure, the solution was vacuum-filtered using 0.2 um filter and washed with $1 \mathrm{M} \mathrm{NaCl}$ followed by distilled water and $0.1 \mathrm{M}$ $\mathrm{NaOH}$ solutions. Brine wash resulted only in small amounts of $\mathrm{Se}(\mathrm{IV})$ desorption indicating that only a small fraction of $\mathrm{F}^{-}$ions are held by ion-exchange/electrostatic forces. A nearly complete removal of adsorbed Se(IV) was achieved by alkali wash which overcame all interactions of the sorbent with $\mathrm{Se}(\mathrm{IV})$ through a dominating competition for surface active sites. In short, $\mathrm{Se}(\mathrm{IV})$ could be regenerated relatively easily by treating with an alkaline solution (e.g., 0.1 M NaOH). Sodium hydroxide quantitatively desorbed all bound $\mathrm{Se}(\mathrm{IV})$ without damaging the BMDC which could be reused after washing it with $0.1 \mathrm{M} \mathrm{H}_{2} \mathrm{SO}_{4}$ acid followed by distilled water till neutral $\mathrm{pH}$. Two successive regenerations showed more than $90 \%$ removal efficiency.

\section{Conclusion}

Diatom offers unique architecture with excellent mechanical strength. This paper highlights the potential of diatom as the host for immobilizing nanomaterials to form composite. A bimetallic composite was successfully synthesized for removal of Se from water. This was achieved by precipitating zirconium and iron oxides on the diatom and then oxidizing the organic mass. Maximum Se(IV) adsorption capacity of $277 \mathrm{mg} / \mathrm{g}$ adsorbent was calculated using the Langmuir adsorption isotherm. A variation in $\mathrm{pH}$ between 2 and 6 did not alter the adsorption capacity, but a significant reduction in capacity was seen at $\mathrm{pH}$. The BMDC had a higher adsorption capacity for $\mathrm{Se}(\mathrm{IV})$ when compared with $\mathrm{Se}(\mathrm{VI})$.

\section{Disclosure}

Any opinions, findings, and conclusions or recommendations expressed in this paper are those of the authors and do not necessarily reflect the views of the NJWRRI.

\section{Conflicts of Interest}

The authors declare that they have no conflicts of interest.

\section{Acknowledgments}

The authors would like to thank New Jersey Water Resources Research Institute of Technology (NJWRRI) for partial funding under Grant no. 2016NJ383B.

\section{References}

[1] S. Sharma and R. Singh, "Selenium in Soil, Plant, and Animal Systems," C R C Critical Reviews in Environmental Control, vol. 13, no. 1, pp. 23-50, 1983.

[2] H. M. Ohlendorf, "Bioaccumulation and effects of selenium in wildlife," in Selenium in Agriculture and the Environment(seleniuminagric), pp. 133-177, 1989.

[3] D. Strawn, H. Doner, M. Zavarin, and S. McHugo, "Microscale investigation into the geochemistry of arsenic, selenium, and iron in soil developed in pyritic shale materials," Geoderma, vol. 108, no. 3-4, pp. 237-257, 2002.

[4] C. M. Gonzalez, J. Hernandez, J. R. Peralta-Videa, C. E. Botez, J. G. Parsons, and J. L. Gardea-Torresdey, "Sorption kinetic study of selenite and selenate onto a high and low pressure aged iron oxide nanomaterial," Journal of Hazardous Materials, vol. 211212, pp. 138-145, 2012.

[5] M. G. C. Fernandez, M. A. Palacios, and C. Camara, "Flowinjection and continuous-flow systems for the determination 
of $\mathrm{Se}(\mathrm{IV})$ and $\mathrm{Se}(\mathrm{VI})$ by hydride generation atomic absorption spectrometry with on-line prereduction of $\mathrm{Se}(\mathrm{VI})$ to $\mathrm{Se}(\mathrm{IV})$," Analytica Chimica Acta, vol. 283, no. 1, pp. 386-392, 1993.

[6] S. Santos, G. Ungureanu, R. Boaventura, and C. Botelho, "Selenium contaminated waters: an overview of analytical methods, treatment options and recent advances in sorption methods," Science of the Total Environment, vol. 521-522, no. 1, pp. 246-260, 2015.

[7] W. T. Frankenberger Jr. and M. Arshad, "Bioremediation of selenium-contaminated sediments and water," BioFactors, vol. 14, no. 1-4, pp. 241-254, 2001.

[8] V. Mavrov, S. Stamenov, E. Todorova, H. Chmiel, and T. Erwe, "New hybrid electrocoagulation membrane process for removing selenium from industrial wastewater," Desalination, vol. 201, no. 1-3, pp. 290-296, 2006.

[9] E. I. El-Shafey, "Removal of Se(IV) from aqueous solution using sulphuric acid-treated peanut shell," Journal of Environmental Management, vol. 84, no. 4, pp. 620-627, 2007.

[10] M. O. M. Sharrad, H. Liu, and M. Fan, "Evaluation of FeOOH performance on selenium reduction," Separation and Purification Technology, vol. 84, pp. 29-34, 2012.

[11] J. Das, D. Das, G. P. Dash, and K. M. Parida, "Studies on Mg/Fe hydrotalcite-like-compound (HTlc): I. Removal of inorganic selenite $\left(\mathrm{SeO}_{3}^{2-}\right)$ from aqueous medium," Journal of Colloid and Interface Science, vol. 251, no. 1, pp. 26-32, 2002.

[12] M. Duc, G. Lefèvre, and M. Fédoroff, "Sorption of selenite ions on hematite," Journal of Colloid and Interface Science, vol. 298, no. 2, pp. 556-563, 2006.

[13] M. Martínez, J. Giménez, J. De Pablo, M. Rovira, and L. Duro, "Sorption of selenium(IV) and selenium(VI) onto magnetite," Applied Surface Science, vol. 252, no. 10, pp. 3767-3773, 2006.

[14] N. Zhang, L.-S. Lin, and D. Gang, "Adsorptive selenite removal from water using iron-coated GAC adsorbents," Water Research, vol. 42, no. 14, pp. 3809-3816, 2008.

[15] C. M. Gonzalez, J. Hernandez, J. G. Parsons, and J. L. GardeaTorresdey, "A study of the removal of selenite and selenate from aqueous solutions using a magnetic iron/manganese oxide nanomaterial and ICP-MS," Microchemical Journal, vol. 96, no. 2, pp. 324-329, 2010.

[16] M. Zhang and E. J. Reardon, "Removal of B, Cr, Mo, and Se from wastewater by incorporation into hydrocalumite and ettringite," Environmental Science \& Technology, vol. 37, no. 13, pp. 29472952, 2003.

[17] T. Roussel, C. Bichara, and R. J.-M. Pellenq, "Selenium and carbon nanostructures in the pores of AlPO4-5," Adsorption, vol. 11, no. 1, pp. 709-714, 2005.

[18] I. Bonhoure, I. Baur, E. Wieland, C. A. Johnson, and A. M. Scheidegger, "Uptake of Se(IV/VI) oxyanions by hardened cement paste and cement minerals: An X-ray absorption spectroscopy study," Cement and Concrete Research, vol. 36, no. 1, pp. 91-98, 2006.

[19] W. Sun, W. Pan, F. Wang, and N. Xu, "Removal of Se(IV) and $\mathrm{Se}(\mathrm{VI})$ by $\mathrm{MFe} 2 \mathrm{O} 4$ nanoparticles from aqueous solution," Chemical Engineering Journal, vol. 273, pp. 353-362, 2015.

[20] Y.-T. Chan, W.-H. Kuan, Y.-M. Tzou et al., "Molecular Structures of $\mathrm{Al} / \mathrm{Si}$ and $\mathrm{Fe} / \mathrm{Si}$ Coprecipitates and the Implication for Selenite Removal," Scientific Reports, vol. 6, Article ID 24716, 2016.

[21] C.-G. Lee and S.-B. Kim, "Removal of arsenic and selenium from aqueous solutions using magnetic iron oxide nanoparticle/multi-walled carbon nanotube adsorbents," Desalination and Water Treatment, vol. 57, no. 58, pp. 28323-28339, 2016.
[22] W. Cui, P. Z. Li, S. Wang, Y. Zheng, and Zhang., "Adsorption study of selenium ions from aqueous solutions using $\mathrm{MgO}$ nanosheets synthesized by ultrasonic method," Journal of Hazardous Materials, vol. 341, Supplement C, pp. 268-276, 2018.

[23] Z. Ma, C. Shan, J. Liang, and M. Tong, "Efficient adsorption of Selenium(IV) from water by hematite modified magnetic nanoparticles," Chemosphere, pp. 134-141, 2017.

[24] X. Zhao, L. Lv, B. Pan, W. Zhang, S. Zhang, and Q. Zhang, "Polymer-supported nanocomposites for environmental application: A review," Chemical Engineering Journal, vol. 170, no. 2-3, pp. 381-394, 2011.

[25] M. Ali Atieh, "Removal of chromium (VI) from polluted water using carbon nanotubes supported with activated carbon," in Proceedings of the Urban Environmental Pollution 2010, pp. 281293, USA, June 2010.

[26] S. Sinha Ray, K. Yamada, M. Okamoto, A. Ogami, and K. Ueda, "New polylactide/layered silicate nanocomposites. 3. Highperformance biodegradable materials," Chemistry of Materials, vol. 15, no. 7, pp. 1456-1465, 2003.

[27] C. Caparrós, M. Benelmekki, P. M. Martins et al., "Hydrothermal assisted synthesis of iron oxide-based magnetic silica spheres and their performance in magnetophoretic water purification," Materials Chemistry and Physics, vol. 135, no. 2-3, pp. 510-517, 2012.

[28] N. Ferroudj, J. Nzimoto, A. Davidson et al., "Maghemite nanoparticles and maghemite/silica nanocomposite microspheres as magnetic Fenton catalysts for the removal of water pollutants," Applied Catalysis B: Environmental, vol. 136-137, pp. 9-18, 2013.

[29] M. Kokate, K. Garadkar, and A. Gole, "One pot synthesis of magnetite-silica nanocomposites: applications as tags, entrapment matrix and in water purification," Journal of Materials Chemistry A, vol. 1, no. 6, pp. 2022-2029, 2013.

[30] Z. Liu, H. Wang, C. Liu et al., "Magnetic cellulose-chitosan hydrogels prepared from ionic liquids as reusable adsorbent for removal of heavy metal ions," Chemical Communications, vol. 48, no. 59, pp. 7350-7352, 2012.

[31] X. Yu, S. Tong, M. Ge, J. Zuo, C. Cao, and W. Song, "Onestep synthesis of magnetic composites of cellulose@iron oxide nanoparticles for arsenic removal," Journal of Materials Chemistry A, vol. 1, no. 3, pp. 959-965, 2013.

[32] Y.-C. Chang and D.-H. Chen, "Preparation and adsorption properties of monodisperse chitosan-bound $\mathrm{Fe}_{3} \mathrm{O}_{4}$ magnetic nanoparticles for removal of $\mathrm{Cu}(\mathrm{II})$ ions," Journal of Colloid and Interface Science, vol. 283, no. 2, pp. 446-451, 2005.

[33] Y.-T. Zhou, H.-L. Nie, C. Branford-White, Z.-Y. He, and L.-M. $\mathrm{Zhu}$, "Removal of $\mathrm{Cu} 2+$ from aqueous solution by chitosancoated magnetic nanoparticles modified with $\alpha$-ketoglutaric acid," Journal of Colloid and Interface Science, vol. 330, no. 1, pp. 29-37, 2009.

[34] B. Hansen, P. Kwan, M. M. Benjamin, L. I. Chi-Wang, and G. V. Korshin, "Use of iron oxide-coated sand to remove strontium from simulated Hanford tank wastes," Environmental Science \& Technology, vol. 35, no. 24, pp. 4905-4909, 2001.

[35] C. Ding, X. Yang, W. Liu, Y. Chang, and C. Shang, "Removal of natural organic matter using surfactant-modified iron oxidecoated sand," Journal of Hazardous Materials, vol. 174, no. 1-3, pp. 567-572, 2010.

[36] F. Ge, M. Li, H. Ye, and B. Zhao, "Effective removal of heavy metal ions $\mathrm{Cd}^{2+}, \mathrm{Zn}^{2+}, \mathrm{Pb}^{2+}, \mathrm{Cu}^{2+}$ from aqueous solution by polymer-modified magnetic nanoparticles," Journal of Hazardous Materials, vol. 211-212, pp. 366-372, 2012. 
[37] A. Z. M. Badruddoza, Z. B. Z. Shawon, W. J. D. Tay, K. Hidajat, and M. S. Uddin, " $\mathrm{Fe}_{3} \mathrm{O}_{4} /$ cyclodextrin polymer nanocomposites for selective heavy metals removal from industrial wastewater," Carbohydrate Polymers, vol. 91, no. 1, pp. 322-332, 2013.

[38] A. Farrukh, A. A. Akram, S. Ghaffar et al., "Design of polymerbrush-grafted magnetic nanoparticles for highly efficient water remediation," ACS Applied Materials \& Interfaces, vol. 5, no. 9, pp. 3784-3793, 2013.

[39] S. Addo Ntim and S. Mitra, "Removal of trace arsenic to meet drinking water standards using iron oxide coated multiwall carbon nanotubes," Journal of Chemical \& Engineering Data, vol. 56, no. 5, pp. 2077-2083, 2011.

[40] V. K. Gupta, S. Agarwal, and T. A. Saleh, "Synthesis and characterization of alumina-coated carbon nanotubes and their application for lead removal," Journal of Hazardous Materials, vol. 185, no. 1, pp. 17-23, 2011.

[41] S. Addo Ntim and S. Mitra, "Adsorption of arsenic on multiwall carbon nanotube-zirconia nanohybrid for potential drinking water purification," Journal of Colloid and Interface Science, vol. 375, no. 1, pp. 154-159, 2012.

[42] S. Yang, Z. Guo, G. Sheng, and X. Wang, "Application of a novel plasma-induced CD/MWCNT/iron oxide composite in zinc decontamination," Carbohydrate Polymers, vol. 90, no. 2, pp. 1100-1105, 2012.

[43] M. Mishra, A. P. Arukha, T. Bashir, D. Yadav, and G. B. K. S. Prasad, "All new faces of diatoms: potential source of nanomaterials and beyond," Frontiers in Microbiology, vol. 8, 2017.

[44] F. E. Round, R. M. Crawford, and D. G. Mann, The Diatoms: Biology \& Morphology of the Genera, Cambridge University Press, Cambridge, UK, 1990.

[45] C. E. Hamm, R. Merkel, O. Springer et al., "Architecture and material properties of diatom shells provide effective mechanical protection," Nature, vol. 421, no. 6925, pp. 841-843, 2003.

[46] D. Losic, G. Triani, P. J. Evans, A. Atanacio, J. G. Mitchell, and N. H. Voelcker, "Controlled pore structure modification of diatoms by atomic layer deposition of TiO2," Journal of Materials Chemistry, vol. 16, no. 41, pp. 4029-4034, 2006.

[47] Y. Wang, J. Cai, Y. Jiang, X. Jiang, and D. Zhang, "Preparation of biosilica structures from frustules of diatoms and their applications: Current state and perspectives," Applied Microbiology and Biotechnology, vol. 97, no. 2, pp. 453-460, 2013.

[48] D. Losic, G. Rosengarten, J. G. Mitchell, and N. H. Voelcker, "Pore architecture of diatom frustules: Potential nanostructured membranes for molecular and particle separations," Journal of Nanoscience and Nanotechnology, vol. 6, no. 4, pp. 982-989, 2006.

[49] Z. Bao, M. R. Weatherspoon, S. Shian et al., "Chemical reduction of three-dimensional silica micro-assemblies into microporous silicon replicas," Nature, vol. 446, no. 7132, pp. 172$175,2007$.

[50] C. Jeffryes, J. Campbell, H. Li, J. Jiao, and G. Rorrer, “The potential of diatom nanobiotechnology for applications in solar cells, batteries, and electroluminescent devices," Energy \& Environmental Science, vol. 4, no. 10, pp. 3930-3941, 2011.

[51] Y. Wang, D. Zhang, J. Pan, and J. Cai, "Key factors influencing the optical detection of biomolecules by their evaporative assembly on diatom frustules," Journal of Materials Science, vol. 47, no. 17, pp. 6315-6325, 2012.

[52] M. S. Aw, S. Simovic, Y. Yu, J. Addai-Mensah, and D. Losic, "Porous silica microshells from diatoms as biocarrier for drug delivery applications," Powder Technology, vol. 223, pp. 52-58, 2012.

[53] A. Gélabert, O. S. Pokrovsky, J. Schott et al., "Study of diatoms/aqueous solution interface. I. Acid-base equilibria and spectroscopic observation of freshwater and marine species," Geochimica et Cosmochimica Acta, vol. 68, no. 20, pp. 40394058, 2004.

[54] A. Gélabert, O. S. Pokrovsky, J. Schott, A. Boudou, and A. Feurtet-Mazel, "Cadmium and lead interaction with diatom surfaces: A combined thermodynamic and kinetic approach," Geochimica et Cosmochimica Acta, vol. 71, no. 15, pp. 3698-3716, 2007.

[55] N. Chubar, "New inorganic (an)ion exchangers based on $\mathrm{Mg}-\mathrm{Al}$ hydrous oxides: (Alkoxide-free) sol-gel synthesis and characterisation," Journal of Colloid and Interface Science, vol. 357, no. 1, pp. 198-209, 2011.

[56] M. Szlachta, V. Gerda, and N. Chubar, "Adsorption of arsenite and selenite using an inorganic ion exchanger based on Fe-Mn hydrous oxide," Journal of Colloid and Interface Science, vol. 365, no. 1, pp. 213-221, 2012.

[57] T. M. Suzuki, M. L. Tanco, D. A. P. Tanaka, H. Matsunaga, and T. Yokoyama, "Adsorption characteristics and removal of oxoanions of arsenic and selenium on the porous polymers loaded with monoclinic hydrous zirconium oxide," Separation Science and Technology, vol. 36, no. 1, pp. 103-111, 2001.

[58] B. Pan, J. Xu, Z. B. Wu, Z. Li, and X. Liu, "Enhanced removal of fluoride by polystyrene anion exchanger supported hydrous zirconium oxide nanoparticles," Environmental Science \& Technology, vol. 47, no. 16, pp. 9347-9354, 2013.

[59] N. M. Price, G. I. Harrison, J. G. Hering et al., "Preparation and chemistry of the artificial algal culture medium Aquil," Biological Oceanography, vol. 6, no. 5-6, pp. 443-461, 1989.

[60] M. Thakkar, Z. Wu, L. Wei, and S. Mitra, "Water defluoridation using a nanostructured diatom- $\mathrm{ZrO} 2$ composite synthesized from algal Biomass," Journal of Colloid and Interface Science, vol. 450, pp. 239-245, 2015.

[61] J. A. Wang, L. F. Chen, M. A. Valenzuela et al., "Surfactantassisted synthesis of defective zirconia mesophases and $\mathrm{Pd}$ / ZrO2: Crystalline structure and catalytic properties," Applied Surface Science, vol. 254, no. 16, pp. 5061-5072, 2008.

[62] A. K. Singh and U. T. Nakate, "Microwave synthesis, characterization, and photoluminescence properties of nanocrystalline zirconia," The Scientific World Journal, vol. 2014, Article ID 349457, 7 pages, 2014.

[63] M. Szlachta and N. Chubar, "The application of Fe-Mn hydrous oxides based adsorbent for removing selenium species from water," Chemical Engineering Journal, vol. 217, pp. 159-168, 2013.

[64] J. Q. Dalagan and E. P. Enriquez, "Interaction of Diatom Silica with Graphene," Phillippine Science Letters, vol. 6, no. 1, pp. 119127, 2013.

[65] M. Guan, W. Liu, Y. Shao, H. Huang, and H. Zhang, "Preparation, characterization and adsorption properties studies of 3(methacryloyloxy)propyltrimethoxysilane modified and polymerized sol-gel mesoporous SBA-15 silica molecular sieves," Microporous and Mesoporous Materials, vol. 123, no. 1-3, pp. 193201, 2009.

[66] K. Möller, J. Kobler, and T. Bein, "Colloidal suspensions of nanometer-sized mesoporous silica," Advanced Functional Materials, vol. 17, no. 4, pp. 605-612, 2007.

[67] H.-M. Kao, T.-Y. Shen, J.-D. Wu, and L.-P. Lee, "Control of ordered structure and morphology of cubic mesoporous 
silica SBA-1 via direct synthesis of thiol-functionalization," Microporous and Mesoporous Materials, vol. 110, no. 2-3, pp. 461-471, 2008.

[68] S. Lagergren, "About the theory of so-called adsorption of soluble substances," Kungliga Svenska Vetenskapsakademiens Handlingar, vol. 24, no. 4, pp. 1-39, 1898.

[69] Y. S. Ho and G. McKay, "The kinetics of sorption of divalent metal ions onto sphagnum moss peat," Water Research, vol. 34, no. 3, pp. 735-742, 2000.

[70] Y.-S. Ho, "Citation review of Lagergren kinetic rate equation on adsorption reactions," Scientometrics, vol. 59, no. 1, pp. 171-177, 2004.

[71] E. Bulut, M. Özacar, and I. A. Şengil, "Adsorption of malachite green onto bentonite: equilibrium and kinetic studies and process design," Microporous and Mesoporous Materials, vol. 115, no. 3, pp. 234-246, 2008.

[72] I. Langmuir, "The adsorption of gases on plane surfaces of glass, mica and platinum," Journal of the American Chemical Society, vol. 40, no. 9, pp. 1361-1403, 1918.

[73] H. Freundlich, "Over the adsorption in solution," Journal of Physical Chemistry, vol. 57, Article ID 385471, pp. 1100-1107, 1906.

[74] K. R. Hall, L. C. Eagleton, A. Acrivos, and T. Vermeulen, "Pore- and solid-diffusion kinetics in fixed-bed adsorption under constant-pattern conditions," Industrial \& Engineering Chemistry Fundamentals, vol. 5, no. 2, pp. 212-223, 1966.

[75] P. K. Malik, "Dye removal from wastewater using activated carbon developed from sawdust: adsorption equilibrium and kinetics," Journal of Hazardous Materials, vol. 113, no. 1-3, pp. 81-88, 2004.

[76] V. Poots, G. J. McKay, and Healy., "Removal of basic dye from effluent using wood as an adsorbent," Journal (Water Pollution Control Federation), pp. 926-935, 1978.

[77] D. Peak and D. Sparks, "Mechanisms of selenate adsorption on iron oxides and hydroxides," Environmental Science \& Technology, vol. 36, no. 7, pp. 1460-1466, 2002.

[78] M. Barathi, A. Santhana Krishna Kumar, and N. Rajesh, "A novel ultrasonication method in the preparation of zirconium impregnated cellulose for effective fluoride adsorption," Ultrasonics Sonochemistry, vol. 21, no. 3, pp. 1090-1099, 2014.

[79] S. S. Ramamurthy, Y. Chen, M. K. Kalyan, G. N. Rao, J. Chelli, and S. Mitra, "Carbon nanotube-zirconium dioxide hybrid for defluoridation of water," Journal of Nanoscience and Nanotechnology, vol. 11, no. 4, pp. 3552-3559, 2011.

[80] M. Tuzen and A. Sari, "Biosorption of selenium from aqueous solution by green algae (Cladophora hutchinsiae) biomass: Equilibrium, thermodynamic and kinetic studies," Chemical Engineering Journal, vol. 158, no. 2, pp. 200-206, 2010.

[81] Y. Fu, J. Wang, Q. Liu, and H. Zeng, "Water-dispersible magnetic nanoparticle-graphene oxide composites for selenium removal," Carbon, vol. 77, pp. 710-721, 2014.

[82] Y. T. Chan, W. H. Kuan, T. Y. Chen, and M. K. Wang, "Adsorption mechanism of selenate and selenite on the binary oxide systems," Water Research, vol. 43, no. 17, pp. 4412-4420, 2009.

[83] A. W. Lounsbury, J. S. Yamani, C. P. Johnston, P. LareseCasanova, and J. B. Zimmerman, "The role of counter ions in nano-hematite synthesis: implications for surface area and selenium adsorption capacity," Journal of Hazardous Materials, vol. 310, pp. 117-124, 2016. 

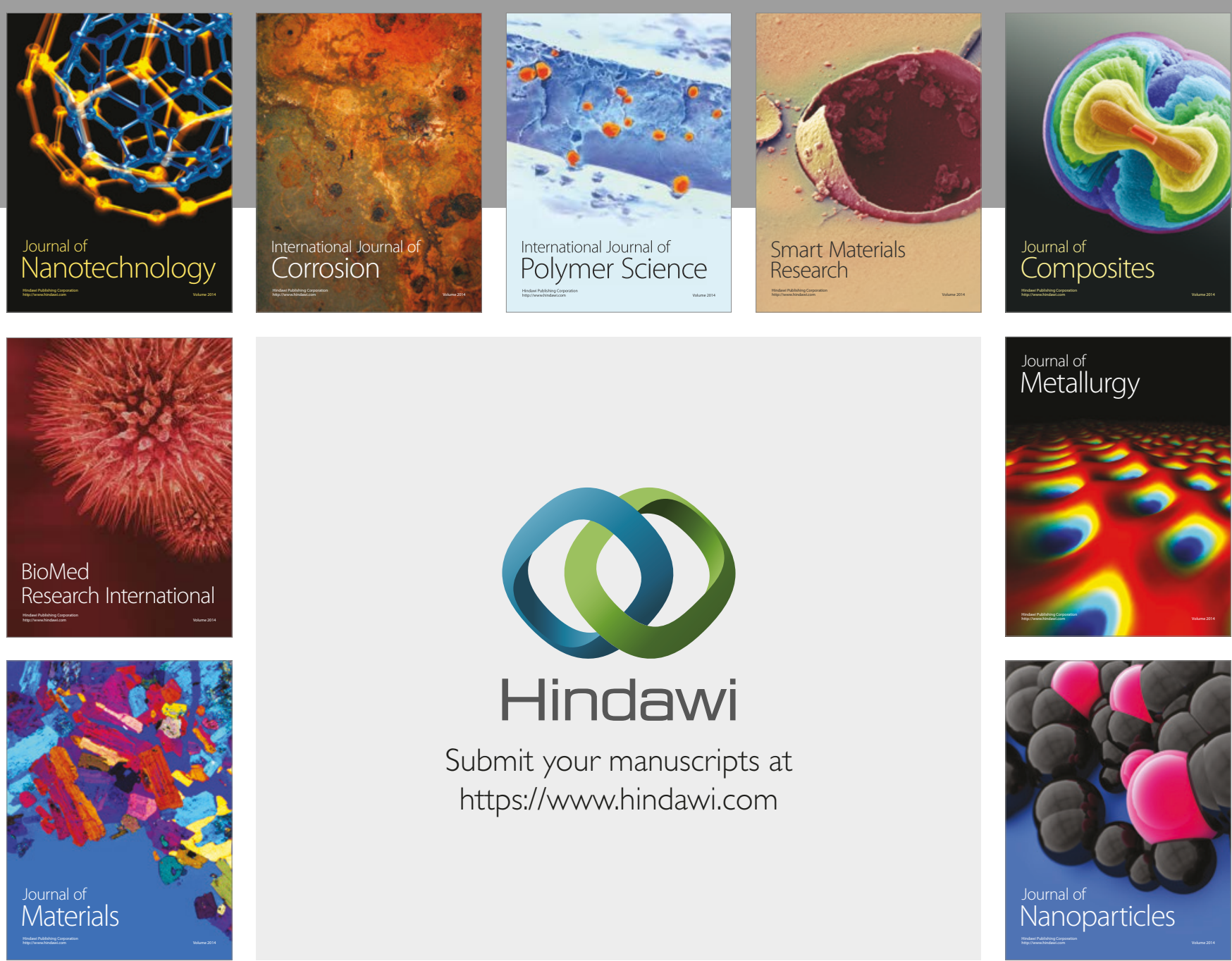

\section{Hindawi}

Submit your manuscripts at

https://www.hindawi.com
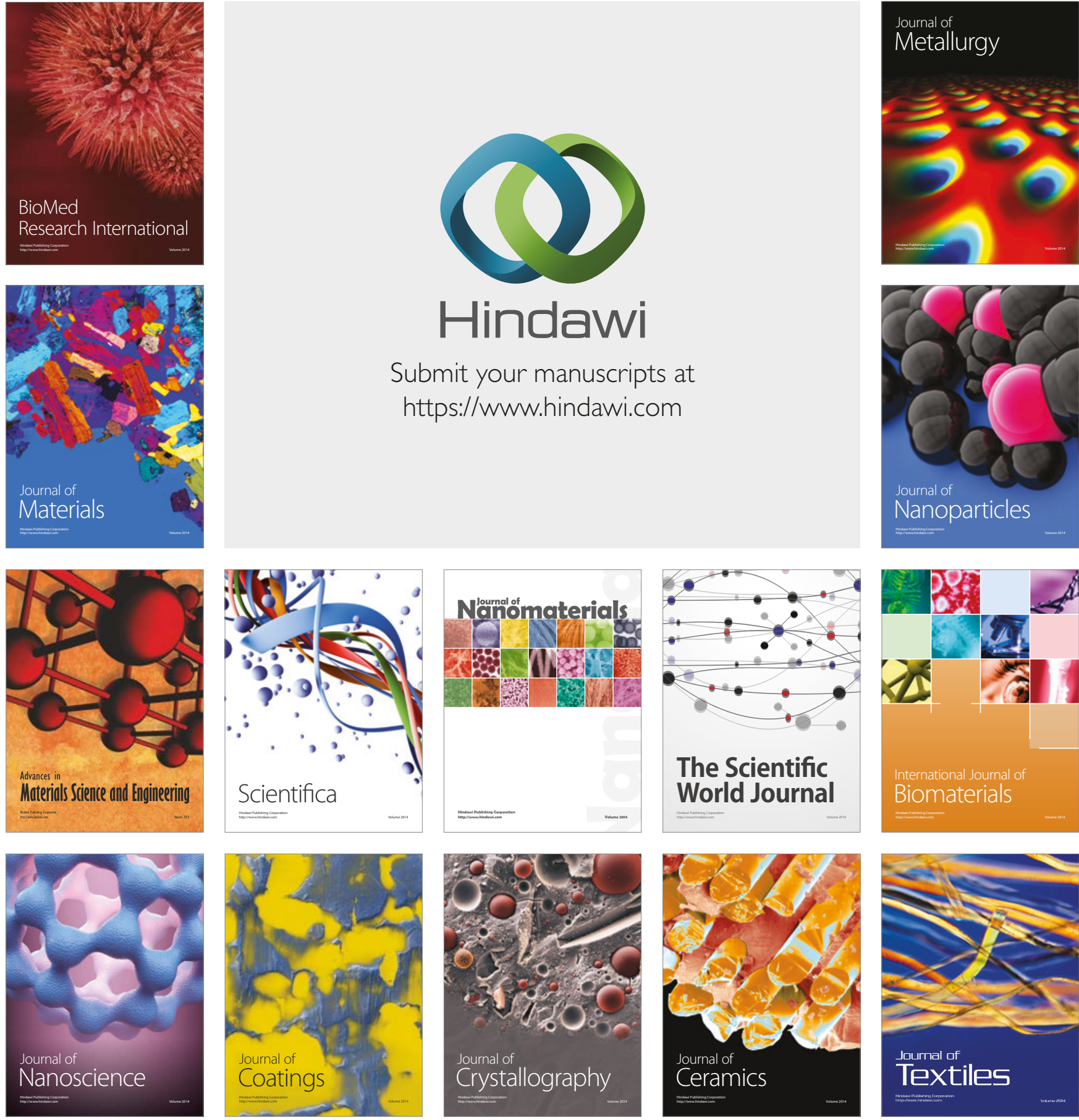

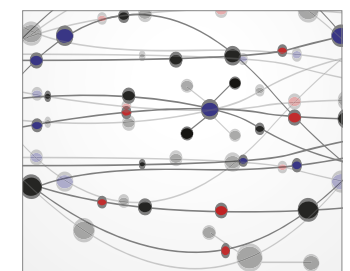

The Scientific World Journal
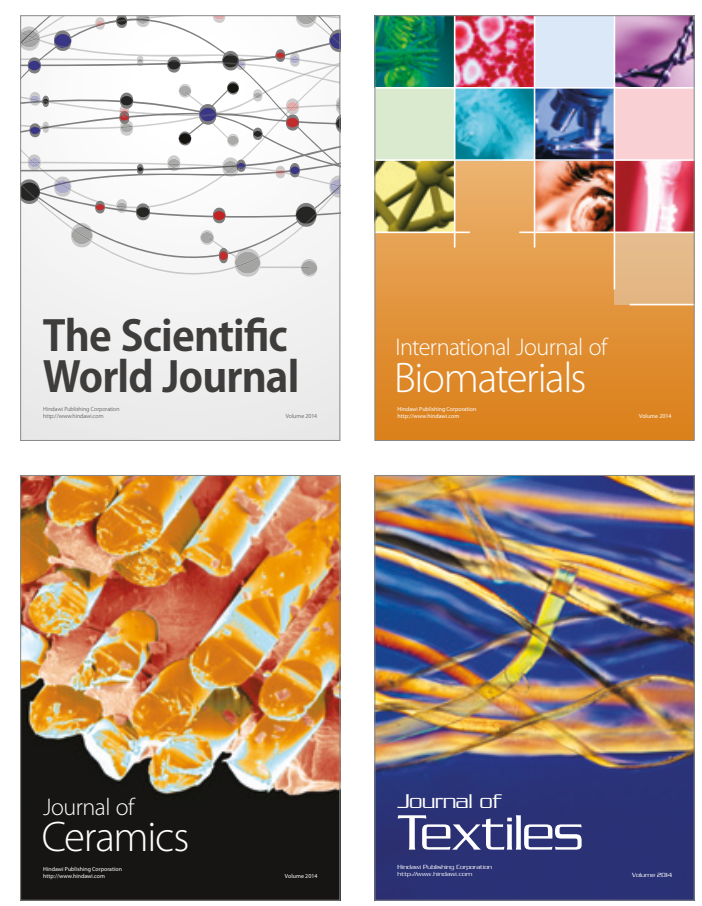